\title{
Р.П.Соловій,
}

кандидат історичних наук, старший науковий співробітник Центру дослідження релігії НПУ імені М.П.Драгоманова

\section{ПОСТМОДЕРНИЙ ПРОТЕСТАНТИЗМ: ХРИСТОЛОГІЧНІ ІННОВАЦІЇ ВИНИКАЮЧОЇ ЦЕРКВИ}

Богослови новітньої течії західного протестантизму, відомої як Виникаюча церква, пропонують оригінальну христологічну доктрину, яку, на нашу думку, варто дослідити в конструюванні загальної картини сучасної протестантської думки. Оскільки аналітичних праць, які стосуються заявленої ними теми, практично немає, то звернемося безпосередньо до творів богословів, представників Виникаючої церкви. Їхні автори: С. Берк, С.Гренц, А. Джонс, Д. Кімбелл, Б. Макларен, Д.Паджітт, Б. Тейлор.

Метою нашої статті є релігієзнавчо-богословське дослідження христологічної доктрини Виникаючої церкви.

У протестантському постмодерністському богослов'ї христологічна доктрина зазнає суттєвого переосмислення, переважно в руслі постконсервативної парадигми. Зокрема, один із іiі розробників, С.Гренц, відмовився від традиційної «христології зверху» і віддає перевагу більш сучасній «христології знизу», згідно з якою знання про Христа можуть бути здобуті лише з нашого досвіду про Нього в історії і в нашому житті, а не з біблійних богословських тверджень [4, 324-341]. Сам Ісус, на думку Гренца, не стверджував, що Він $є$ Месією, а був визнаним таким після Свого воскресіння. Відтак віра грунтується не на припущенні, що Біблія правдива, а на Його воскресінні і на історичній достовірності Його тверджень. Ці висновки, зроблені завдяки емпіричним дослідженням, приводять нас до віри в Ісуса і до визнання Біблії як книги Його народу. Гренц переглядає багато традиційних богословських термінів, що описують особистість Ісуса. Він не вірить в існування Ісуса до Його народження, в класичному розумінні, і заперечує будь-які з'явлення Христа, про які йдеться в Старому Завіті. Спокутування дослідник розглядає в універсальному сенсі - як «покриття» всіх гріхів світу, тож, мовляв, Бог може простити будь-кого, хто приходить до Нього. Гренц вважає, що класичні визначення спокутування (викуп, умилостивлення) - це 
метафори, взяті з культури того часу, в якому їх було сформульовано.

У цьому ж руслі рухається думка основних богословів руху Виникаючої церкви. Зокрема, Б.Макларен стверджує, що церква перебуває на початковій стадії радикального переоцінювання Iсуса: «Все більше й більше людей відкривають для себе новий погляд на Iсуса, який здається менш похмурим, ірраціональним і біполярним, і більш послідовним, цілеспрямованим, мужнім» $[8,154,155]$. Симптоматичним є приклад Р.Белла, який створює гіпотетичну ситуацію $\mathrm{i}$ намагається з'ясувати, чи було б можливим продовження існування християнства, якби було доведено, «що Ісус мав реального, земного, біологічного батька на ім'я Ларрі <...> і що непорочне зачаття було лише міфологічним епізодом, який вставили автори Євангелій?» $[1,26]$. Белл не вбачає жодної проблеми в такому тлумаченні народження Ісуса, хоча його твердження підриває основні доктрини християнської віри - богонатхненності Святого Писання, вчення про непорочне зачаття, втілення, поєднання природ Христа, зрештою - про Його замісницьку смерть.

Остання $з$ перелічених доктрин викликає особливо гострі заперечення у богословів руху. Хоча учасники руху слушно нагадують, що слід звертати увагу на всі існуючі теорії спокутування, багато хто 3 них загалом не залишають місця для доктрини замісницького відкуплення. Вони визнають, що Ісус був замісником, але заперечують ідею, згідно з якою Він зазнав покарання за людей і віддають перевагу христологічній моделі Христа Переможця (Christus Victor), за якою Ісус заплатив Своїм життям викуп сатані і прийняв на Себе гнів Отця замість грішників. Деякі автори натякають на те, що доктрина замісницького відкуплення виглядає як «божественне жорстоке поводження з дитиною», бо Отець вимагає життя Свого Сина, перш ніж Він буде готовим пробачити грішників $[11,102]$. Зокрема, кардинальне переоцінювання значення смерті Христа здійснює А.Джонс, який заперечує вчення про замісницьке відкуплення. Він вважає, що «церква повинна перестати зосереджуватись на смерті Ісуса як на універсальному спасаючому акті і місце хреста має бути переосмислене в християнській вірі. Чому? Через культ страждання і мстивого Бога, Який стоїть за цим культом» $[5,132]$. С.Берк також відкидає доктрину замісницької смерті Христа, не погоджуючись 3 біблійним твердженням про те, що метою приходу Ісуса на землю було померти як жертва умилостивлення за гріхи людей. Богослов вважає, що з усіх елементів християнства найбільш огидним $є$ по- 
няття Христа, Який взяв на Себе наші гріхи і приніс Своє тіло в агонії, щоб врятувати наші душі. Проте постає питання: хіба люди просили Його це робити? Чому, в такому разі, Ісус помер? Відповідь Берка - Своєю жертовною любов'ю Він створював загрозу для тогочасної релігійної спільноти.

На думку Берка, кращий підхід полягає в тому, щоб розглядати Ісуса як модель безгрішного життя, досконалий приклад, до якого все людство має прагнути [2, ix, х]. Слід обережно ставитися до традиційного вчення про замісницьке відкуплення, бо воно здатне посилювати карикатурне уявлення про Бога, що є «сердитим, кровожерливим, караючим». Зрештою, на думку С.Берка, спасіння людини залежить не від наявності у неї віри в певну систему доктрин, а від того, чи провадить вона цілісне життя, чи готова вона приєднатися до Ісуса в Його візії перетвореного людства [2, 130-131]. Подібну христологічну концепцію розвиває Д.Паджітт. Наявна в його системі відмова від учень про первородний гріх і вроджену гріховність людства, про значення Бога як судді й посмертну відплату, не залишала місця для Ісуса-Спасителя. Паджітт доходить думки, що Ісуса слід розглядати у світлі історії євреїв Старого Завіту, беручи за взірець Мойсея та Ісуса Навіна - провідників на шляху ізраїльтян до Обіцяного краю, а також приклади партнерства з Богом.

Причина легковажного ставлення до традиційних христологічних формулювань полягає в тому, що для багатьох ідеологів руху Ісус є дорогою і правдою не в тому сенсі, що Він є втіленням правди і єдиним шляхом до Бога, а в тому, що «шлях Iсуса є найкращий можливий шлях життя» $[1,20]$.

Розглядаючи христологічні питання, лідери Виникаючої церкви мають тенденцію переносити наголос на значення морального прикладу Христа, відсуваючи на другий план роль Христа як жертви за очищення від гріха: «Що ми маємо на увазі під «шляхом Ісуса Христа»? <...> Життя Ісуса Христа і Його взаємодія 3 культурою, як це втілено в уявленнях спільноти, з урахуванням словесного вираження в Нагірній проповіді, становлять перспективу для християн. Модерні розуміння Ісуса мають тенденцію звільнитися від Його життя і зосередитися на Його смерті й воскресінні, а також на внутрішньому досвіді тих, хто вірить у Христа. Але було навпаки, Ісус вітав ізгоїв, давав притулок чужинцям і кидав виклик політичній владі, створюючи альтернативну спільноту. Все життя Iсуса, зокрема Його слова, становлять шлях Ісуса Христа, i саме 
цей шлях значною мірою вплинув на Виникаючі церкви <...> Виникаючі церкви - це спільноти, які практикують шлях Ісуса Христа в культурі постмодерну» $[3,44]$.

Якщо найбільшою метою людства, як стверджують автори руху, $\epsilon$ егоїстичне життя, то Ісус може змінити нас, просто будучи досконалою рольовою моделлю любові та співчуття в ставленні до ближніх. Його смерть на хресті в такому разі буде не більше, ніж зразковою демонстрацією Божої любові до світу. Отже, богослови руху починають із твердження, що Бог хоче, щоб ми наслідували приклад Христа, беручи участь у Його спокутній діяльності у всьому світі. Однак традиційно протестантська теологія наголошувала, що грішники не можуть відповісти на євангельську звістку одним лише наслідуванням любові Ісуса. Вони мають визнати, що через притаманну їм гріховність заслуговують на справедливий гнів Божий, а також мають повірити в смерть Христа на хресті як спокутну жертву для прощення гріхів. Перш ніж Христос стане нашим моральним взірцем, Він повинен стати розіп'ятим Месією.

Далекою від традиційної є христологічна доктрина Б. Макларена. Він вважає, що Ісус став «жертвою вкраденої ідентичності», адже Його ім'я використовується для виправдання дій, які Ісус ніколи б не вчинив. 3 цим твердженням важко не погодитися - в Боже ім'я і справді робилося чимало злочинів. Причину численних спотворень образу Ісуса Макларен пов'язує з впливом греко-римського наративу християнства і конституційного підходу до Біблії. У наявності різних версій прочитання життя і вчення Ісуса Макларен вбачає i позитивний фактор: 3 кожної них можна почерпнути щось корисне [7, 43-67]. Тут проявляється властива богослов'ю Макларена тенденція до екуменізму, згідно з якою християнські традиції розглядаються як елементи мозаїки, які доповнюють одна одну.

Пошук Ісуса, Який би відповідав устремлінням Макларена, почався з сумніву в традиційному протестантському акценті на смерті Христа, який (акцент) начебто маргіналізує життя Ісуса. Як далі пише автор, «з часом я почав відчувати, що 3 моєї точки зору євангеліє стало просто індивідуалістичною теорією й абстракцією особистого, але не глобального значення. Це стосувалося вирішення всесвітніх правових, бізнесових, політичних проблем, реальних і серйозних, але трохи сухих, трохи віддалених від реального життя. У моєму серці зросло глибоке, тонке, невисловлене почуття, що чогось бракує, яке поступово відкрило моє серце для 
пошуку інших шляхів розуміння Iсуса» [Ibid., 48-49]. Макларен закликає до відродження первісного образу Христа і з цією метою звертається до тексту Об. 19, 11-16, який, за його словами, часто використовується для обгрунтування поширеного серед християн погляду на Ісуса як на могутнього Вождя, який в останні часи 3 мечем у руці встановить на землі Свій порядок.

Макларен стверджує, що зображення Ісуса у книзі Об'явлення як завойовника мало на меті запевнити віруючих першого століття, що мирний Ісус, який постає в євангельській розповіді, не був переможений, а Його звістка прощення і примирення зрештою виявиться могутнішою від мечів і списів Цезаря. Ісус Об'явлення не відмовився від учення про мир, прощення і любов до ворогів. Саме в цьому Макларен вбачає важливість Ісуса: Він являє Собою живу альтернативу греко-римському наративу, що визначав обличчя християнства стільки часу. Об'явлення переконує, що покірний проповідник примирення і є могутнім Господом, що бідний і беззбройний галілеянин заслуговує на довіру. За Маклареном, книга Об'явлення проголошує не любов до сили, але силу любові, відкидаючи уявлення про Христа, Який відомстить усім, хто не віддає Йому належної шани, i, висуваючи натомість образ Христа-Визволителя, що простягає Свою милість навіть до тих, хто завдавав йому ран, Макларен доходить висновку, що значення Ісуса полягає в тому, що «повний, сяючий, славний досвід Бога в Ісусі Христі революціонізував всю концепцію Бога, так що зазнало переосмислення саме слово Бог» [Ibid., 73]. Зрештою, ми самі вирішуємо, яка версія Христа нам до вподоби і в якого Бога нам хотілося б вірити.

Макларен поділяє також властиву руху недовіру до теорії замісницького відкуплення, яка, на його переконання, постає просто як ще одна несправедливість у космічному рівнянні. Це схоже на божественне насильство над дитиною. Насправді, вважає Макларен, «хрест закликає людство припинити намагання здійснити Царство Боже шляхом примусу і сили, які в остаточному підсумку завжди приречені на провал, а замість цього радо прийняти його через самопожертву і сприйнятливість» $[11,106]$.

Богослов розгортає свої міркування. «Якщо Бог хотів простити нас, - запитує Макларен, - то чому Він просто нас не простив? Чому Ісус мав померти, щоб ми могли бути прощені? Віддання невинної людини на смерть за винних людей, здається, не вирішує «несправедливості» прощення - це тільки додало несправедливості. 
Отже, чому Ісус мав померти?» [9, 80]. На думку Макларена, страждання і смерть Христа мали подвійну мету: символічно зобразити доброту Бога, а також показати Його бажання простити і вирішити проблему страждання. Очевидно, що така відповідь не враховує вчення про замісницьке відкуплення, згідно з яким причиною смерті Христа було те, що Бог не міг простити людство без покарання гріха. Але причина цього полягає не в тому, що, як каже Ніл в історії Макларена, Бог - це «хороший хлопець, який потрапив у важку ситуацію. Він хоче пробачити нас, але повинен грати за правилами суду» $[10,40]$. Однак, згідно з історичним євангельським богослов'ям, коли Бог прощає гріх, Його спонукують до цього не зовнішні закони, а Його власна праведна і любляча природа. Оскільки Бог є любов'ю і джерелом життя, то егоїзм, який є протилежністю Його, неминуче повинен призвести до смерті. Через те, що гріх обов'язково закінчується смертю, Бог не може прощати гріхи без жертви. Тепер, коли Бог заплатив те, що вимагала Його любляча і праведна природа, ми можемо прощати інших, не вимагаючи від них відшкодування завданого нам зла. Коли ми прощаємо іншим особам, ми просто передаємо Боже прощення. Оскільки єдиною причиною, чому можемо прощати інших, не вимагаючи їх покарання, $\epsilon$ те, що Бог уже заплатив за нас, то ті, хто критикує Бога за недостатню великодушність, не розуміють сутності хреста.

Наступна тема, до якої звертається Макларен, стосується традиційного (особливо для протестантів) погляду, згідно з яким основною метою приходу Христа було спасти людей від пекла після смерті, а не розв'язувати соціальні проблеми поцейбічного життя. Макларен різко критикує такий богословський підхід. Як може серйозний християнин стверджувати, що Ісуса не цікавили питання бідності й рабства, як можна ігнорувати слова Ісуса про бідних, Його ставлення до пригнічених? - запитує він. Посилаючись на новозавітні тексти, що стосуються соціальних проблем, Макларен стверджує, що їх слід розглядати не в традиційних рамках гріхопадіння, перворідного гріха, відкуплення, пекла і раю, а в контексті запропонованої автором версії біблійного наративу, основними моментами якого є історія творення і примирення (Буття), історія визволення й формування (Вихід) та історія Ісаї про нове творення і царство миру. У межах цієї перспективи дослідник розглядає Свангеліє від Івана.

На його думку, початок Свангелія і чудеса Ісуса (зцілення, за- 
безпечення їжею голодних, воскресіння мертвого) перекликаються 3 силою життя і творення, явленою Богом у книзі Буття. При цьому відбувається переосмислення поняття «вічного життя», яке розуміється не як життя після смерті або вічне життя на небесах, а як життя, що «перевершує» реалії нинішнього часу. Відповідно, «народження згори» трактується як «народження у нове творіння», у встановлений Богом порядок творіння, що суперечить «сучасному злому часу» (Гал. 1, 4). Паралель між наративами про життя Ісуса $\mathrm{i}$ творіння в книзі Буття Макларен убачає і в першій появі Ісуса після воскресіння в саду, який перегукується 3 добротою саду Едему. Перспектива визволення, розвинута у книзі Вихід, на думку Макларена, резонує в житті Ісуса завдяки подібності Його історії з історією Мойсея (початкове відкинення близькими, визволення від поневолення, скинія як місце перебування Бога і втілення Христа, левитські жертви).

Обіцяна земля, за Маклареном, становить основну тему третього виміру його версії біблійного наративу. Поступово ідея Обіцяного краю трансформується 3 географічного в соціальне поняття: «земля, що тече молоком і медом», стає суспільством, в якому справедливість тече як ріка. Обіцяна земля стає царством миру, гармонії, соціальної рівності, процвітання і безпеки. Макларен підкреслює, що метою появи Христа було не стільки спасіння душ від пекла, скільки розв'язання соціальних проблем. За словами богослова, Він прийшов, щоб дати початок новому Буттю, здійснити новий Вихід і проголосити, втілити й ознаменувати нове царство миру. Саме в рамках цього наративу Макларен убачає відновлення справжнього образу Ісуса.

Варто зауважити, що Макларен переважно не стверджує, що Iсус $\epsilon$ Богом. 3 його текстів може скластися враження, що Ісус звичайна людина, яка прагне звільнити людство від жорстокості й дати досконалий приклад миру і примирення. Думка Макларена про те, що важливість Ісуса зумовлена тим, що Він становить альтернативу греко-римському наративу, не знаходить підтримки ні в Біблії, ані в християнській традиції. Тлумачення деталей може бути різним, але традиційно християнське богослов'я дотримується підходу, згідно з яким важливість Христа зумовлена перша за все Його онтологічною унікальністю (поєднанням Божественної і людської природ, що уможливило Його смерть на хресті за наші гріхи і Його воскресіння для нашого оправдання). Саме неповторність Особи й 
діла Ісуса Христа визначають силу його морального впливу. Навіть якщо погодитися з точкою зору Макларена щодо мети приходу Христа, то все ж важко зрозуміти, яким саме чином життя і вчення Христа сприяють здійсненню цієї мети. Адже Макларен не пов'язує Ісуса з розв'язанням проблеми гріха. За його словами, Ісус прийшов, щоб спасти людей від гріха гноблення, а не щоб врятувати їх від гноблення гріха. Наголошуючи на етичному виміpi служіння Ісуса, на Його меті примирення, Макларен не звертає уваги на відкуплення, прощення, суд. Це зумовлено його загальним розумінням християнського наративу, в якому немає місця для тем первородного гріха, розриву стосунків із Богом, розуміння «гріхопадіння» як відчуження від Бога. Звідси виникає ще одне запитання: яким чином Ісус може дати початок новому Буттю, здійснити новий Вихід і проголосити, втілити й ознаменувати нове царство Князя миру, не поклавши край пануванню гріха у світі, не прийшовши вдруге як Суддя?

Слід зазначити, що більш помірковані богослови руху дотримуються традиційних христологічних формулювань. Наприклад, Д.Кімбелл, попереджаючи про небезпеку як надто фамільярного ставлення до Ісуса, так і Його фундаменталістського прочитання, намагається відтворити «стародавній» образ Христа. Його Ісус це Друга особа Трійці, єврейський рабин, гідний подиву вчитель, співчутлива особистість, захисник бідних і пригноблених, критик законництва. Він взяв на Себе гріхи людства, хоча Сам був без гріха; здійснив наше відкуплення завдяки Своїй замісницькій смерті; закликає Своїх послідовників провадити місіонерське життя. Одного дня Він повернеться, щоб судити живих і мертвих.

Із досліджень провідних богословів Виникаючої церкви випливає, що христологічна доктрина цього сучасного євангельського руху міститься в смисловому полі постконсервативної парадигми. С.Гренц відкидає традиційну «христологію зверху» і віддає перевагу «христології знизу», вважаючи, що знання про Христа можуть бути отримані лише з людського досвіду про Нього в історії і в житті, а не $з$ біблійних богословських тверджень, у яких класичні визначення спокутування (викуп, умилостивлення) - це метафори, взяті 3 греко-римської культури. А. Джонс, С. Берк відкидають доктрину замісницької смерті Христа, заперечуючи біблійне твердження про те, що метою приходу Ісуса на землю було померти як жертва умилостивлення за гріхи людства. Берк сприймає Ісуса як модель 
безгрішного життя, досконалий приклад, до якого людина повинна прагнути. Тим часом традиційне вчення про замісницьке відкуплення здатне посилювати карикатурне уявлення про караючого i жорстокого Бога.

Богослови Виникаючої церкви акцентують на значенні морального прикладу Христа, Який повинен виступати досконалою рольовою моделлю любові та співчуття у ставленні до ближніх. Водночас відсувається на другий план Його роль як жертви за очищення від гріха. Постмодерні богослови вважають, що страждання і смерть Христа мали подвійну мету: символічно зобразити доброту Бога та показати Його бажання простити й вирішити проблему страждання. Виникаюча церкви критикує богословський підхід, згідно з яким основною метою приходу Христа було спасти людей від пекла після смерті, а не розв'язувати соціальні проблеми поцейбічного життя, пропонуючи розглядати новозавітні тексти, котрі стосуються соціальних проблем, не в традиційних рамках гріхопадіння, первородного гріха, відкуплення, пекла і раю, а в контексті старозавітних наративів творіння і примирення (Буття), визволення й формування (Вихід) та вчення пророка Ісаї про нове творіння й царство миру.

\section{ЛІТЕРАТУРА}

1. Bell R. Velvet Elvis: Repainting the Christian Faith. - Grand Rapids: Zondervan Publishing House, 2005. - 194 p.

2. Burke S. A Heretic's Guide to Eternity. - San Francisco: Jossey-Bass, 2006.- 288 p.

3. Gibbs E., Bolger R. Emerging Churches: Creating Christian Community in Postmodern Cultures. - Grand Rapids: Baker Academic, 2005. - 352 p.

4. Grenz S. Theology for the Community of God. - Nashville: Broadman \& Holman Publishers, 1994. - 723 p.

5. Jones A. Reimagining Christianity: Reconnect Your Spirit without Disconnecting Your Mind. - Hoboken: John Wiley \& Sons, Inc., 2005. - 288 p.

6. Kimball D. They Like Jesus but Not the Church. - Grand Rapids: Zondervan, 2007. $-272 \mathrm{p}$.

7. McLaren B. A Generous Orthodoxy. - Grand Rapids: Zondervan Publishing House, 2004. -352 p.

8. McLaren B. Everything Must Change: Jesus, Global Crises, and a Revolution of Hope. - Nashville: Thomas Nelson, 2007. - 322 p.

9. McLaren B. More Ready Than You Realize: Evangelism as Dance in the 
Postmodern Matrix. - Grand Rapids: Zondervan, 2002. - 188 p.

10. McLaren B. The Last Word and the Word After That: A Tail of Faith, Doubt, and a New Kind of Christianity. - San Francisco: Jossey-Bass, 2005. - 337 p.

11. McLaren B. The Story We Find Ourselves In: Further Adventures of a New Kind of Christian. - San Francisco: Jossey-Bass, 2003. - 336 p.

Соловій Р.П. Постмодерний протестантизм: христологічні інноваиії Виникаючої иеркви.

У статті показано, що христологічну доктрину Виникаючої церкви, одну з найбільш радикальних течій постмодерного протестантизму, переосмислено в руслі постконсервативної теологічної парадигми, згідно 3 якою знання про Христа можна бути здобути лише з людського досвіду про Нього в історії і в житті, а не з біблійних богословських тверджень. А класичні визначення спокутування (викуп, умилостивлення) - це метафори, запозичені християнством з греко-римської культури. Богослови Виникаючої церкви заперечують ідею замісницької смерті Ісуса Христа, бо вона створює уявлення про караючого і жорстокого Бога. Автор акцентує увагу на значенні морального прикладу Христа, відсуваючи на другий план розгляд ролі Христа як жертви за очищення від гріха.

Ключові слова: христологія, Виникаюча церква, протестантське богослов'я, Біблія.

Соловий Р. Постмодерный протестантизм: христологические инновачии Появляющейся церкви.

В статье показано, что христологическая доктрина Появляющейся церкви, одного из наиболее радикальных течений постмодернистского протестантизма, переосмыслена в русле постконсервативной парадигмы, согласно которой знания о Христе могут быть получены только из человеческого опыта о Нем в истории и в жизни, а не из библейских богословских утверждений. Классические же определения искупления (откуп, умилостивления) - это метафоры, позаимствованные из греко-римской культуры. Богословы Появляющейся церкви отрицают идею заместительной смерти Иисуса Христа, ибо она создает представление о карающем и жестоком Боге. Автор акцентирует внимание на значении нравственного примера Христа, отодвигая на второй план рассмотрение роли Христа как жертвы очищения от греха.

Ключевые слова: христология, Иисус Христос, Появляющаяся церковь, протестантское богословие, Библия.

Soloviy R. Postmodern Protestantism: Christological Innovations of Emerging Church.

The aim of this article is to analyze the Christological doctrine of the 
Emerging church. The theologians of this church rethought the traditional Christological doctrine in accordance with the post-conservative theological paradigm. They insist that the knowledge of Christ could be obtained not through the biblical theological statements but only based on human experience of Him in history and in life. The key thinkers of the Emerging church claim that classic definition of redemption includes- metaphors (redemption, propitiation) taken from the Greco-Roman culture. They reject the idea of the atoning death of Jesus Christ because it creates the image of punishing and cruel God. Some Emerging church theologians reject the doctrines of original sin and the innate sinfulness of humanity. The movement emphasizes importance of the moral example of Christ, rejecting the role of Christ as a sacrifice for purification of $\sin$.

Key words: Christology, Jesus Christ, Emerging church, Protestant theology, the Bible. 